\title{
Chemical characterisation of museum-curated ethnographic resins from Australia and New Guinea used as adhesives, medicines and narcotics
}

\author{
Fiona Bradshaw
}

\begin{abstract}
Background: Six ethnographic museum resins with documented adhesive, medicinal and narcotic uses have been analysed by gas chromatography-mass spectrometry (GC-MS) as a step towards understanding the role of specific resins in $20^{\text {th }}$ century Australia and New Guinea. Curated in the Pitt Rivers Museum for over a hundred years, these specimens are examples of resin used for three different purposes, some accompanied by ethnographic accounts from the collectors themselves.

Results: The six ethnographic resins have been chemically characterised and identified to species where possible: an adhesive resin from New South Wales is identified as Xanthorrhoea resinosa Pers.; adhesives from New Guinea are tentatively identified as Canarium luzonicum Miq. and beeswax mixed with Canarium spp.; a narcotic resin from New Guinea is identified as Canarium salomonense B.L.Burtt; and the characterisation of spinifex resin from West Australian 'medicine shells' hypothesised to be Triodia irritans R.Br is presented.

Conclusions: This study concludes that molecular differentiation between resins from different species is still possible after a hundred years of aging in a museum environment and demonstrates the potential of resin analysis on such aged museum items. These data alongside re-visited ethnographic accounts can confirm, correct, or provide new information to museum records. Furthermore, they can shed new light on the study of the role of these particular resins and mixtures that were used in Indigenous Sahul and contribute towards a framework of analysis and understanding of archaeological resins from this region.
\end{abstract}

Keywords: Resin analysis, Pitt Rivers Museum, Xanthorrhoea, Triodia, Canarium, Indigenous uses of resin, Ethnographic resin, Sahul, GC-MS

\section{Background}

Since European contact, the indigenous populations of Australia and New Guinea (former Sahul) have been intensively studied through ethnography and archaeology. This has provided us with three main sources of insight into both social and environmental interactions practised by these people, namely ethnographic accounts, ethnographic artefacts and archaeological research. Applying scientific techniques to old materials allow us to extend the range of our insights, particularly from objects held in museum

\section{Correspondence: fiona.bradshaw@rlaha.ox.ac.uk}

Research Laboratory for Archaeology and the History of Art (RLAHA),

University of Oxford, Dyson Perrins Building, South Parks Road, Oxford OX1 3QY, England collections and accompanied by collection data. These collections often include organic materials that can enhance our understanding of plant exploitation practices, use of natural materials, and development of technologies.

One important organic material for researching these areas is natural plant resin. Resin is known to have been an important material to the inhabitants of Australia and Papua New Guinea for thousands of years, particularly in its role as a hafting adhesive [1-3]. In Australia, Robertson [4] concluded that hafting methods appeared to vary with the morphology of the tool, and evidence of brownish-black, red-brown and yellow residues suggest the use of resins from at least three different sources.
() Chemistry Central

(c) 2013 Bradshaw; licensee Chemistry Central Ltd. This is an open access article distributed under the terms of the Creative Commons Attribution License (http://creativecommons.org/licenses/by/2.0), which permits unrestricted use, distribution, and reproduction in any medium, provided the original work is properly cited. 
Ochre and other materials, including dried and powdered polysaccharide gums, are known to be added to resin as fillers to reduce the brittle character of some resins, particularly spinifex and Xanthorrhoea [5,6]. Dickson [5] concludes, "The use of natural resins as bonding agents for composite tools was a highly sophisticated part of aboriginal technology which probably took a long time to develop empirically." Processing resin for effective use involves skill as excessive heating hardens it permanently to a brittle mass, and the details of processing resins for use varies in different parts of Australia [5].

However, despite the range of resin resources in Australia and Papua New Guinea, we know very little about the role of resin in indigenous communities. The focus of instrumental resin analysis for archaeological research is often centered on the hafting of composite tools $[7,8]$, which although extremely important, has been criticised for being too dominant, leading to the exclusion of the study of other functions of such resins [9].

This study presents results from a gas chromatography-mass spectrometry (GC-MS) analysis of six early-twentieth-century resin specimens that have been curated in the Pitt Rivers Museum in Oxford for the majority of their post-collection life of one hundred years or so. These objects are ethnographical specimens with documented general resin type and purpose, in some cases with some additional ethnographic information, and are examples of three different uses of resin in Sahul; as adhesives, medicines and narcotics. The range of resins available and potentially used by past inhabitants of Australia and Papua New Guinea is considerable and identification of the species of botanical origin of a resin is the first step towards gaining knowledge about the way resins were exploited.

This paper aims (i) to ascertain whether resin specimens of over a hundred years old, and kept in a museum environment, maintain enough chemical markers to allow firm identification of their botanical source; (ii) to re-visit and add new information to museum records through scientific analysis of the museum resins within the context of current ethnographic information; and (iii) to work towards developing a framework for understanding the role of resins in Australia and New Guinea in the more distant past. It is part of a larger study that is aimed at understanding the functionality of resins in these regions, including how people selected resins for different uses, how they manipulated or altered them such as by mixing or heating to better suit that purpose, and what this tells us about their technology and material culture.

The importance of this research lies in its contribution towards understanding natural material use in Australia and New Guinea. It also contributes to large- scale archaeological questions about early and subsequent inhabitants and their adaptation to their surroundings, the nature of their human-environment relationship, plant exploitation methods and implementation of cultivation and domestication, and the development of technologies. It may also hold some significance in offering indigenous communities research into 'lost' or less well-known traditions. This research demonstrates the importance of museum collections for archaeological and ethnographic research and the benefits of scientific methods such as GC-MS.

\section{Indigenous resin use in Australia and Papua New Guinea}

Plant resin has a large number of desirable characteristics, including water-resistance, anti-microbial and biocide properties, adhesiveness, and thermo-plasticity (i.e. its ability to become malleable when heated). It is used in Australia and Papua New Guinea for hafting heads onto shafts of composite tools, waterproofing baskets and bark buckets, caulking boats, and making and decorating ornamental items. Plant resin also burns well, has a pleasant aroma, and can be mixed with other materials, and thus is also used for illumination, incense, medicinal and narcotic purposes, and as a paint binder $[10,11]$. Resin preserves relatively well and is periodically found in an archaeological context. While ethnographers have also recorded plant exudates such as polysaccharide gums, saps and latexes as useful products, resins are more likely to survive archaeologically as they are not water-soluble and are often contained by or adhered to long-lasting materials such as pottery, stone, obsidian or shell.

Resin use may have a lineage back to the earliest inhabitants of Sahul, 40,000 - 50,000 years ago [12,13] and by studying ethnographic objects, clues to aspects of that lineage, such as resin selection, procurement and modification, may become apparent and allow a more focused and informed analysis of archaeological resins. Ethnographic artefacts can also provide an increased range of examples and insights into the use of resin where archaeological insight is limited, and help to improve our methods for analysing and understanding archaeological finds, as has been demonstrated in previous residue studies [14].

Xanthorrhoea and spinifex, and Canarium are the most commonly referenced resins for use in Australia and New Guinea respectively. Xanthorrhoea is a grasstree from the Xanthorrhoeaceae family that is endemic to Australia [15]. There are around twenty-eight different species, eight of which produce resin in significant quantities. These species are known for their importance as a source of resin for Aboriginal Australian use, including for fixing spearheads to shafts, which were often made from the centre spike of the plant. Xanthorrhoea 
is thought to be a useful trade item for Aborigines, trading to tribes who did not have access to it [16]. The resinous species within this genus are geographically distinct (Figure 1), which makes Xanthorrhoea resin a very useful tool for locating the source of an artefact and identifying likely trade of completed objects. Being able to molecularly identify the resin of different species of Xanthorrhoea is particularly important, as they are botanically very difficult to differentiate.

Spinifex is another ethnographically significant resin in Australia. Spinifex comes from the genus Triodia, which is another type of grass-like or porcupine tree, from the family Poaceae [15] and is also endemic to Australia. Around twenty-eight of its sixty-nine species are resinous, the most common species referenced for resin-use being $T$. pungens and $T$. irritans [16,17]. It is noted by Pitman and Wallis [9] that these two species along with T. basedowii appear to be the only species mentioned in early ethnographic accounts of spinifex use. The species within this genus are again very difficult to distinguish botanically and there is much geographical crossover between species, each having a fairly wide geographical distribution. Spinifex resin is known to have been used as a hafting adhesive for making composite tools such spears and attaching handles to a range of tool and weapons [16] and is thought to have been preferable to Xanthorrhoea for hafting, due to its ability to be reheated and re-modelled several times without going brittle as Xanthorrhoea does [18]. The preparation of spinifex for hafting use is similar to that of Xanthorrhoea, and is fairly complex. Detailed descriptions are discussed elsewhere $[5,16,19]$.

Canarium is a large genus in the Burseraceae family, consisting of around seventy-seven species, stretching from the African tropics across to Indo-Malaysia [15]. It is of particular interest in Papua New Guinea, a native home of Canarium luzonicum, which produces the commercially important Manila Elemi, used around the world for varnishes, ointments and aromatherapy. Canarium resin is used locally in Papua New Guinea for different purposes including caulking boats, making torches, and making tonics. Canarium indicum is referred to as the canarium nut tree because of its nut-like fruits [15] and in the Solomon Islands C. indicum is known as the Canarum almond

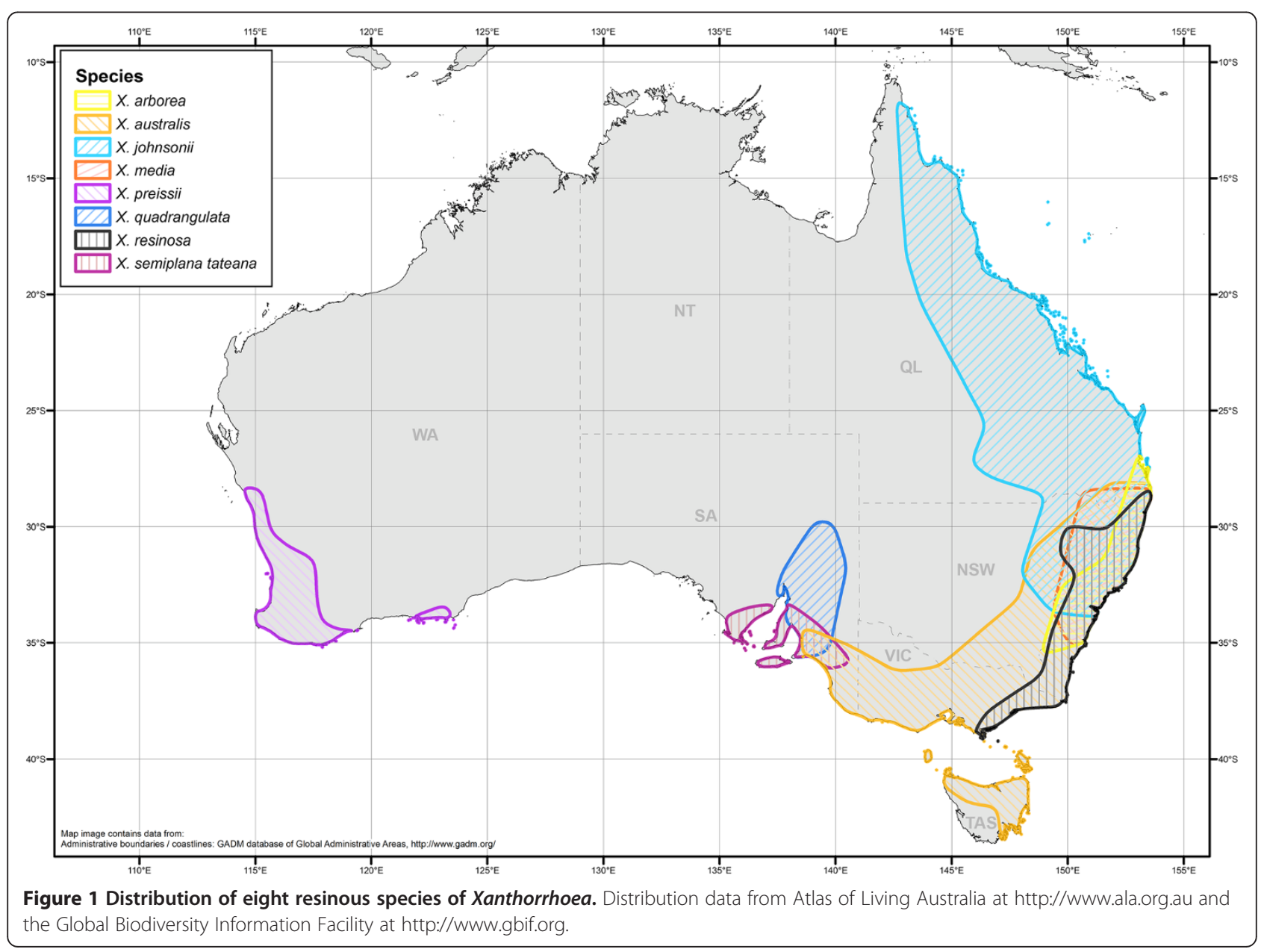


for the same reason, as is $C$. salomonense and $C$. harveyi. McClatchey et al. [20] also notes a spiritual importance of C. salomonense in the northwest Solomon Islands, over other species including $C$. indicum, which is also commonly used in the Solomon Islands and Papua New Guinea. They found that $C$. salomonense held more importance than C. indicum not because it was more important as a food resource (C. indicum nuts were eaten more often) but because $C$. salomonense trees were considered 'sacred'. "Generally, C. salomonense is viewed as a critical resource but $C$. indicum can serve as a substitute in some but not all situations" [20] and McClatchey et al. noted that there was much more discrimination between use and importance of the species' for healing, religious/ceremonial/ritualistic occasions, warfare, food storage/harvest/preparation and property ownership in favour of C. salomonense.

\section{Sample description and ethnographic context}

Six resin specimens from the archives of the Pitt Rivers Museum were included in this study (Table 1). The first specimen from the collection, PRM23, is a lump of raw resin from New South Wales collected in 1914 and labelled Xanthorrhoea. The second and third museum items PRM25 and PRM26 are two similar "medicine shells" each consisting of a cowrie shell filled with resin labelled as spinifex, collected in 1924 in Western Australia. A description of how these items were used is provided by Clement and Schmeltz [21]: "When a member of the tribe falls ill, the boonangharries...are set in motion, and the taketa, dressed up in feather Ornaments... and painted with white and red stripes, walks and struts round the sick person in huge circles, which get smaller and smaller until he is close to the prostrate patient, when he suddenly pounces upon him, rubbing vigorously the affected part with his hands, or a cowry-shell, Cypraea Scottii,..." The two shells in the museum collection, however, have been recorded as 'Cypraia incipiens' and 'Cypraia serpentis', which are not currently accepted species, but may be mistaken for the 'deceptive cowrie' Cypraea decipiens Smith (accepted name Zoila decipiens Smith) and 'serpent's head cowrie' Cypraea caputserpentis (accepted name Erosaria caputserpentis Linnaeus). Cypraea scottii known as 'friend's cowrie' now has the accepted name of Zoila friendii friendii Gray, which does also occur in Western Australia.

There is reference to spinifex under four different local names by Clement and Schmeltz [21]: Culladie, scented gum used for making beads; Cuyallie gum, described as, "gum; obtained from burned grass (Spinifex = Triodia irritans)"; Burga, the same as Cuyallie but cleaned; and Bulga, described as "gum obtained by burning green Spinifex", the latter used for both decorative beads and for fastening spear-heads to shafts for fighting purposes. This suggests there are at least two distinct types of resin in use, Triodia irritans as mentioned, and perhaps a second species, most likely Triodia pungens, which is commonly known as 'green spinifex' and grows in Western Australia. There is no specific reference to resin in the medicine shells by Clement and Schmeltz [21] and 'gum' used for other medicinal items are simply "spinifex-gum". The hypothesis for these items was that the resin in the medicine shells is most likely $T$. pungens or T.irritans.

PRM27 and PRM28 are samples from two boxes containing four balls of resinous material. They both come from the same source along Collingwood Bay (the village is called Wanigela, not Wanigera as is on the museum label) in New Guinea (Table 1), however one of these boxes was labelled as wax and the other as resin. There are several instances where beeswax and resin have been mixed together for various purposes $[7,22,23]$. It is possible that 'Kemeri' in the description for PRM27 could be a version or mis-spelling of kenari, the local name for Canarium indicum. Canarium indicum is endemic to and a big resin producer in Papua New Guinea and its near-by islands. No reference to 'fiufiu', the local name used for PRM28, has yet been found. PRM27 and PRM28 are both examples of material intended probably for stock and later use as adhesives by the Ubir people of Collingwood Bay in the Oro Province of Papua New Guinea.

PRM29 is labelled as Canarium almond gum 'tagon', and was collected in 1930 from Bougainville in the Northern Solomon province of New Guinea. According to Blackwood [24], "They [the people of Buka and Bougainville] like to mix with their tobacco a resinous gum (tagon) collected from the trunk of the canarium almond." Blackwood [25] noted that only one variety of tobacco (Nicotiana tabacum L.) was cultivated in the upper Watut. This variety was common throughout New Guinea. Tobacco was introduced to New Guinea in the 1500's and was grown and used by the Papuan aborigines before Europeans settled there permanently [26]. Later, European trade brought sticks of tobacco, which were often preferred by the Kukukuku and used as a form of currency [25]. Blackwood [24] noted that, "When they have no tobacco they will pick up a piece of smouldering wood from a fire, crush it into their pipes, and smoke it with apparent content." This suggests that the resin is the important component of the smoking mixture, rather than the tobacco. The museum notes for PRM29 labels it as a narcotic.

\section{Scientific analysis of resins}

Gas chromatography-mass spectrometry was selected for this study because of its high sensitivity and accuracy, providing a comprehensive analysis of complex organic materials. It also requires very small sample sizes, which is particularly important for museum and archaeological sampling. GC-MS is the main tool used for chemically characterising archaeological resins in art and 
Table 1 Descriptions of the six museum artefacts sampled in this study

\begin{tabular}{|c|c|c|c|c|c|c|}
\hline Sample & Artefact Description & Geographical Origin & $\begin{array}{l}\text { Collector and Date } \\
\text { Collected }\end{array}$ & Photograph & Notes & $\begin{array}{l}\text { Description } \\
\text { of sample }\end{array}$ \\
\hline PRM23 & $\begin{array}{l}\text { "Xanthorrhea ('blackboy') } \\
\text { gum from the base of a } \\
\text { burnt grass-tree stem." }\end{array}$ & $\begin{array}{l}\text { Near Mount Victoria } \\
\text { in the Blue Mountains, } \\
\text { New South Wales, } \\
\text { Australia }\end{array}$ & $\begin{array}{l}\text { Henry Balfour, } \\
23 \text { August } 1914\end{array}$ & & $\begin{array}{l}\text { Local name: 'black boy' } \\
\text { Function: Adhesive } \\
\text { Accession number: } \\
\text { 1914.38.3 }\end{array}$ & $\begin{array}{l}\text { Deep red, } \\
\text { brittle }\end{array}$ \\
\hline PRM25 & $\begin{array}{l}\text { "Cowrie [shell] filled with } \\
\text { spinifex gum, used by the } \\
\text { TAKETA (doctor) for rubbing } \\
\text { over the affected part." }\end{array}$ & $\begin{array}{l}\text { Sherlock River, } \\
\text { (NW) Western } \\
\text { Australia }\end{array}$ & $\begin{array}{l}\text { Emile Clement, } \\
\text { by } 1924\end{array}$ & & $\begin{array}{l}\text { Cultural group: Ngarluma } \\
\text { (Gnalluma) } \\
\text { Function: Medicinal } \\
\text { Catalogue card: } \\
\text { "Medicine" shell } \\
\text { (Cypraia serpentis) filled } \\
\text { with gum. The Taketa } \\
\text { (doctor) rubs the patient } \\
\text { with this. Length of shell } \\
6 \mathrm{~cm} \text {. } \\
\text { Accession number: } \\
1924.63 .11\end{array}$ & Black, hard \\
\hline
\end{tabular}


Table 1 Descriptions of the six museum artefacts sampled in this study (Continued)

PRM26 Cowrie filled with spinifex $\quad$ Sherlock River, (NW) Emile Clement,

gum, used by the

gum, used by the TAKETA

the affected part.

by 1924

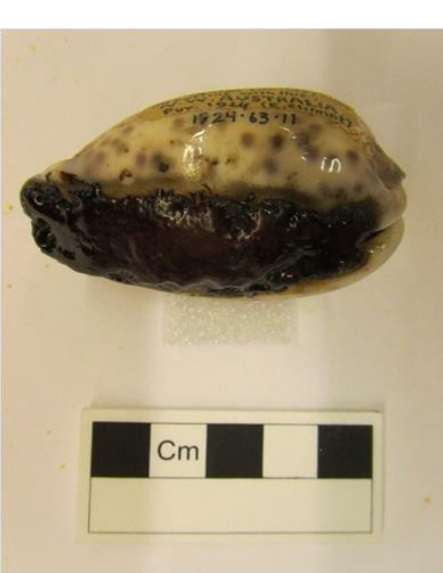

Cultural group: Ngarluma

Function: Medicinal

Yellowish

Catalogue card

"Medicine" shell (Cypraia

incipiens) filled with gum.

The Taketa (doctor) rubs

the patient with this.

Length of shell $4.8 \mathrm{~cm}$.

Accession number:

1924.63.12

black, glassy

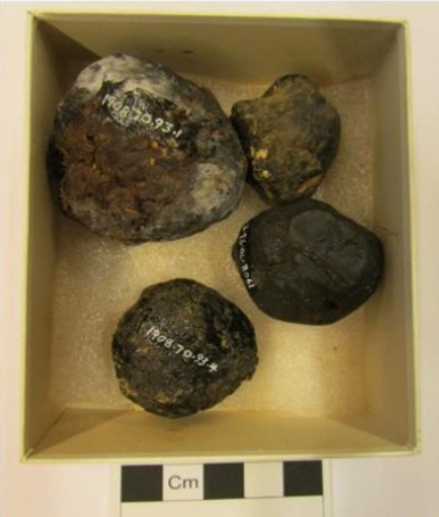

Cultural group: Ubir

Function: Adhesive

Local name: kemeri

Catalogue card: "Wax,

Kemeri, from wild bees'

nests, for fixing ornamental

seeds, beads, etc"

Accession number:

1908.70.93 
Table 1 Descriptions of the six museum artefacts sampled in this study (Continued)

\begin{tabular}{llll}
\hline PRM28 & $\begin{array}{l}4 \text { lumps of bee's wax or } \\
\text { resin used as an adhesive. }\end{array}$ & $\begin{array}{l}\text { Wanigera, in Collingwood Bay, } \\
\text { Oro Province, British New }\end{array}$ & $\begin{array}{l}\text { W.H. Chignell, } \\
\text { by } 1908\end{array}$
\end{tabular}

Guinea

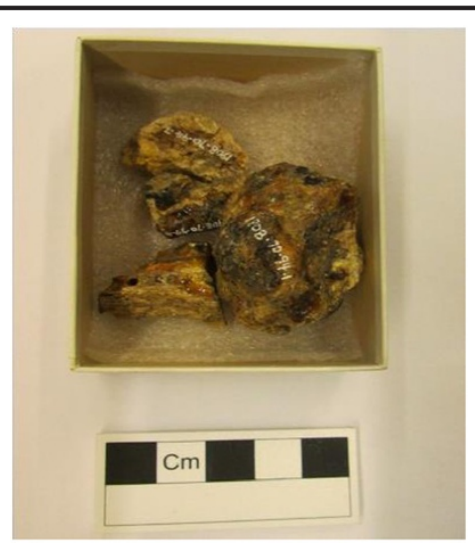

Cultural group: Ubir

Local name: fiufiu

Yellowy

Function: Adhesive

Catalogue card: "fiufiu,

resin used as

an adhesive".

Accession number:

1908.70 .94

$$
1908.70 .94
$$

PRM29

"Gum from the canarium almond tree. Mixed with tobacco to make a cool smoke. In a native packet of palm leaf."
Kurtachi, Bougainville, Northern Solomons

province of Papua New

Guinea
Beatrice Blackwood, 1930

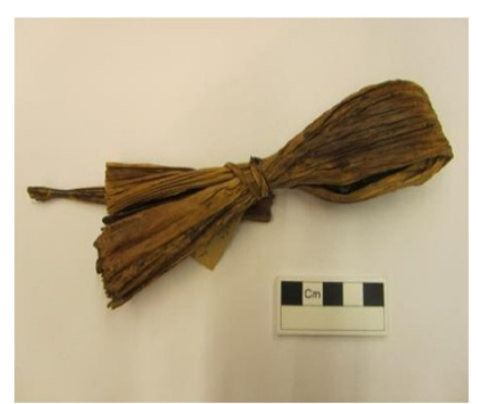

Cultural group: Kurtachi village

Local name: tagon

Function: Narcotic

Catalogue card: "Tagon Gum from

canarium almond tree.

Mixed with

tobacco to make a cool

smoke.

In a native packet of palm

leaf."

$17 \mathrm{~cm}$ width $c .4 .8 \mathrm{~cm}$

Colour dark brown.

Accession number:

1931.86.335 
archaeology with the subsequent comparison of the molecular compositions with fresh modern resins for genus or species identification [27-30].

\section{Results and discussion Sample PRM23}

The chromatogram for PRM23 is fairly complex, however, amongst several significant components of the ethnographic Xanthorrhoea sample (Table 2), the biomarker cinnamyl cinnamate was detected. The chromatogram for PRM23 was compared to those from reference samples of the eight Xanthorrhoea species shown in Figure 1. Cinnamyl cinnamate was detected in the modern reference samples of Xanthorrhoea arborea and X. resinosa, but not in X. australis, X. johnsonii, X. media, X. preissii, X. quadrangulata or $X$. semiplana tateana. Many of the other significant components were detected in each of the reference species, in different combinations, however the whole suite of significant components in PRM23 was only present in $X$. resinosa. The chromatograms for each species are significantly different and demonstrate that species identification of Xanthorrhoea resin is possible by molecular analysis. PRM23 is therefore identified as Xanthorrhoea resinosa Pers.

PRM23 is an example of a resin intended for use as an adhesive in Australia. It was labeled as Xanthorrhoea resin, taken directly from the plant. It has been identified in this study as $X$. resinosa, which makes sense geographically, based on the current botanical distribution of this species (Figure 1) and the fact that the specimen was recorded as coming from New South Wales. No anthropogenic alterations were expected as the resin had not been processed for storage, and was collected as a raw specimen in 1914. This specimen of resin, although not processed itself, will be useful for comparison with processed examples to elucidate any alterations that have taken place as a result of human processes by acting as a control sample for natural degradation processes on this particular species. It is highly likely that this resin was collected for use in hafting, however, the specific use is not recorded in the collection data, and Australian Aborigines have used resin adhesives for a number of purposes.

\section{Samples PRM25 and PRM26}

No modern species comparisons of the two museum 'spinifex' samples were made due to a lack of reference material for Triodia resins. However, the chromatograms for both museum samples (Figure 2, Table 2) showed the presence of the compound vanillin, which occurs in Triodia but is also a component of cypress pine (Callitris spp.) as well as Xanthorrhoea in much lesser amounts, and cinnamic acid-related components some of which also occur in Xanthorrhoea. Comparisons with modern samples of the latter two genera suggest this resin is unlikely to be entirely from either Callitris or Xanthorrhoea, however, there is a possibility that the contents of the cowrie shells are composites of more than one material. Though no other specific biomarkers have been identified as yet in these 'spinifex' samples, the chromatograms overall are very similar and likely to represent the same species or composite. The mass spectra from PRM25 and PRM26 (Table 2) were compared with those of the components listed by de Silva et al. [33] as being the main components of the spinifex resin of Triodia pungens. There was no significant correlation between the suite of compounds listed by de Silva et al. [33] and those of the museum 'spinifex' samples, suggesting that the medicine shell resin is not Triodia pungens.

PRM25 and PRM26 have not been confirmed as 'spinifex' resin as they did not match the molecular composition described in the literature [33] and have not as yet been compared to modern Triodia spp. samples. With the rejection of the hypothesis that the 'spinifex' in the medicine shells is Triodia pungens, it seems likely that it might be Triodia irritans, based on the documented use of the species by the Gnalluma people of Western Australia [21]. It is unlikely that there would have been any deliberate discrimination between different species of Triodia, as they are thought to have the same properties and thus the resin from the most locally available species would have been used. However, in its use as a medicinal rub, the anti-microbial properties of the resin would likely be of prime importance, although, as pointed out by Pitman and Wallis [6], texts dedicated to the descriptions of medicinal plants by Maiden [34], Cribb and Cribb [16] and others, have no mention of spinifex or Triodia as useful for medicinal purposes. The choice of resin may have had a religious/spiritual aspect for the intended medicinal purpose; however, there is no mention of the choice behind resin used in 'medicine shells' in the ethnographic record. This study presents the characterisation of an unusual and rarely documented use of 'spinifex', now hypothesised to be T. irritans.

\section{Samples PRM27 and PRM28}

One sample was taken from each box containing four balls of material (PRM27 and PRM28), and although these two specimens come from the same source and are both used as adhesives, they differ in colour and nature (Table 1), as well as molecularly (Table 2). There is a triterpenoid component in both samples, dominated by the $\alpha$ - and $\beta$ amyrins and related components, indicating the presence of a triterpenoid resin and indicative of Canarium spp. Most Canarium spp. have $\alpha$ - and $\beta$-amyrin as the dominant constituents and therefore the presence of such within the sample is not diagnostic to species. However, PRM28 
Table 2 Mass spectral data for significant components in each of the six museum artefacts

\begin{tabular}{|c|c|c|c|c|c|c|c|}
\hline Artefact & $\begin{array}{l}\text { Elution Time } \\
\text { (mins) }\end{array}$ & Peak & $\begin{array}{l}\text { Significant components, } \\
\text { common name }\end{array}$ & $\begin{array}{l}\text { Significant components, } \\
\text { systematic name }\end{array}$ & $\begin{array}{l}\text { Main } \mathrm{m} / \mathrm{z} \text { values, (relative } \\
\text { intensities), base peak in bold, } \\
{\left[\mathrm{m}^{+}\right]}\end{array}$ & Reference & Also present in:* \\
\hline \multirow[t]{11}{*}{ PRM23 } & 11.3 & & Cinnamaldehyde & 2-Propenal, 3-phenyl- & $\begin{array}{l}\text { 51(29), 77(44), 103(55), 104, } 131 \\
(\mathbf{1 0 0 )},[132(59)]\end{array}$ & NIST05 & $\begin{array}{l}\text { Xanthorrhoea arborea; } X \text {. } \\
\text { resinosa }\end{array}$ \\
\hline & 12.8 & & Cinnamic acid, methyl ester & $\begin{array}{l}\text { 2-Propenoic acid, 3-phenyl-, } \\
\text { methyl ester }\end{array}$ & $\begin{array}{l}51(17), 77(34), 103(60), 131(100), \\
{[162(53)]}\end{array}$ & NIST05 & $\begin{array}{l}X . \text { arborea; } X . \text { preissii; } X . \\
\text { quadrangulata; } X . \text { resinosa }\end{array}$ \\
\hline & 14.1 & & Benzaldehyde,3,4-dimethoxy & 3,4-Dimethoxybenzaldehyde & $\begin{array}{l}\text { 51(13), 77(19), 95(27), 151(13), [166 } \\
(100)]\end{array}$ & NIST05 & $X$. arborea; $X$. resinosa \\
\hline & 16.4 & & Cinnamic acid, p-methoxy & 2-Propenoic acid, 3-(4-methoxyphenyl) & $\begin{array}{l}\text { 63(9), 89(15), 118(12), 133(30), } 161 \\
\text { (100), [192(76)] }\end{array}$ & NIST05 & $\begin{array}{l}X . \text { arborea; } X . \text { australis; } X . \text { media; } \\
X . \text { resinosa; } X . \text { semiplana tateana }\end{array}$ \\
\hline & 17.2 & & $\begin{array}{l}\text { Cinnamic acid, p-hydroxy-, } \\
\text { methyl ester }\end{array}$ & $\begin{array}{l}\text { 2-Propenoic acid, 3-(4-hydroxyphenyl)- } \\
\text { methyl ester }\end{array}$ & $\begin{array}{l}\text { 65(14), 91(23), 119(30), 147(100), } \\
{[178(65)]}\end{array}$ & NIST05 & All Xanthorrhoea samples \\
\hline & 23.4 & & $\begin{array}{l}\text { Chalcone, 2',6'-dihydroxy-4'- } \\
\text { methoxy- }\end{array}$ & $\begin{array}{l}\text { 2-Propen-1-one,1-(2,6-dihydroxy- } \\
\text { 4-methoxyphenyl)1-3-phenyl-,[E] }\end{array}$ & $\begin{array}{l}\text { 95(31), 110(15), 138(37), 166(59), } \\
\text { 193(90), [270(100)] }\end{array}$ & NIST05 & $\begin{array}{l}X . \text { australis; } X . \text { preissii; } X . \\
\text { quadrangulata; } X . \text { resinosa; } X \text {. } \\
\text { semiplana tateana }\end{array}$ \\
\hline & 23.5 & & $\begin{array}{l}\text { Cinnamyl cinnamate (Cinnamic } \\
\text { acid, cinnamyl ester) }\end{array}$ & $\begin{array}{l}\text { 2-Propenoic acid, 3-phenyl-, } \\
\text { 3-phenyl-2-propenyl ester }\end{array}$ & $\begin{array}{l}\text { 51(7), 77(16), 103(23), 115(30), 117(32), } \\
\text { 131(100), 219(15), [264(6)] }\end{array}$ & NIST05 & $X$. arborea; $X$. resinosa \\
\hline & 25.7 & & 5-Hydroxy-4,7-dimethoxyflavanone & $\begin{array}{l}\text { 5-Hydroxy-7-methoxy-2-(4- } \\
\text { methoxyphenyl)-2,3-dihydro-4H- } \\
\text { chromen-4-one }\end{array}$ & $\begin{array}{l}\text { 69(6), 91(20), } 121(65), 134(100), 166 \\
(19), 193(16),[300(69)]\end{array}$ & NIST05 & $\begin{array}{l}X . \text { arborea; } X . \text { johnsonii; } X . \text { media; } \\
X . \text { quadrangulata; } X . \text { resinosa }\end{array}$ \\
\hline & 26.3 & & Sakuranin & $\begin{array}{l}\text { (2R)-2-(4-hydroxyphenyl)-7-methoxy- } \\
\text { 5-[(2S,3R,4S,5S,6R)-3,4,5-trihydroxy- } \\
\text { 6-(hydroxymethyl)oxan-2-yl]oxy-2, } \\
\text { 3-dihydrochromen-4-one }\end{array}$ & $\begin{array}{l}\text { 69(18), 95(22), 120(35), 167(92), } 193 \\
(31), \mathbf{2 8 6}(\mathbf{1 0 0}),[448(0)]\end{array}$ & NIST05 & $\begin{array}{l}X . \text { australis; } X . \text { media; } X . \text { preissii; } X \text {. } \\
\text { quadrangulata; } X . \text { resinosa; } X . \\
\text { semiplana tateana }\end{array}$ \\
\hline & 26.4 & $\begin{array}{l}\text { Unk } \\
\text { A }\end{array}$ & - & - & $\begin{array}{l}\text { 65(11), 91(27), 117(56), 147(100), } \\
186(8), 235(14)\end{array}$ & - & $X$. preissii; $X$. resinosa \\
\hline & 26.9 & $\begin{array}{l}\text { Unk } \\
\text { B }\end{array}$ & - & - & $\begin{array}{l}\text { 71(12), 95(13), } 121(13), 138(14), 151 \\
(100), 164(74), 193(14), \\
330(66)\end{array}$ & - & $X$. australis; X. media; $X$. resinosa \\
\hline \multirow[t]{6}{*}{ PRM25 } & 13.1 & a & Vanillin & Benzaldehyde, 4-hydroxy-3-methoxy- & $\begin{array}{l}52(10), 81(22), 123(16), 151(100), \\
{[152(90)]}\end{array}$ & NIST05 & Callitris spp:; Xanthorrhoea spp. \\
\hline & 13.8 & $b$ & Isoeugenol & Phenol, 2-methoxy-4-(1-propenyl)- & $\begin{array}{l}\text { 55(14), 77(27), 103(25), 131(22), } 149 \\
(34),[164(100)]\end{array}$ & NIST05 & \\
\hline & 15.5 & c & - & - & $\begin{array}{l}52(7), 77(4), 108(9), 123(19) \\
\text { 151(100) }\end{array}$ & - & \\
\hline & 16.4 & $d$ & - & - & $\begin{array}{l}51(6), 79(13), 94(5), 122(7), 137(10) \\
\text { 165(100) }\end{array}$ & - & \\
\hline & 18.3 & e & - & - & $\begin{array}{l}51(9), 65(12), 77(18), 91(25), 103(63) \\
131(41), 159(77), 175(32), 191(31) \\
\text { 205(50), 206(100) }\end{array}$ & - & \\
\hline & 25.9 & f & - & - & $\begin{array}{l}\text { 77(7), 137(18), 202(8), } 311(11), 326 \\
(\mathbf{1 0 0 )}\end{array}$ & - & \\
\hline
\end{tabular}


Table 2 Mass spectral data for significant components in each of the six museum artefacts (Continued)

\begin{tabular}{|c|c|c|c|c|c|c|c|}
\hline & 26.8 & g & - & - & $\begin{array}{l}77(24), 123(20), 137(22), 151(100) \\
165(61), 192(43), 206(28), 370(27)\end{array}$ & - & \\
\hline & 27.1 & $\mathrm{~h}$ & - & - & $\begin{array}{l}79(5), 165(100), 203(20), 341(10), \\
384(26)\end{array}$ & - & \\
\hline & 27.3 & i & Cinnamic acid-related & & $\begin{array}{l}\text { 145(47), 161(17), 192(100), } \\
206(29)\end{array}$ & [31] & Xanthorrhoea spp. \\
\hline & 28.4 & j & - & - & $\begin{array}{l}\text { 77(13), 137(100), 165(51), 208(41), } \\
\text { 273(12), 384(8) }\end{array}$ & - & \\
\hline \multirow[t]{10}{*}{ PRM26 } & 13.1 & a & Vanillin & Benzaldehyde, 4-hydroxy-3-methoxy- & $\begin{array}{l}\text { 52(9), 81(24), 123(15), 151(100), } \\
{[152(91)]}\end{array}$ & NIST05 & Callitris spp.; Xanthorrhoea spp. \\
\hline & 13.8 & $\mathrm{~b}$ & Isoeugenol & Phenol, 2-methoxy-4-(1-propenyl)- & $\begin{array}{l}\text { 55(14), 77(26), 103(25), 131(21), } 149 \\
(33),[164(100)]\end{array}$ & NIST05 & \\
\hline & 15.5 & c & - & - & $\begin{array}{l}\text { 52(7), 77(5), 108(9), 123(19), } 151 \\
(\mathbf{1 0 0 )}\end{array}$ & - & \\
\hline & 16.4 & $d$ & - & - & $\begin{array}{l}\text { 51(5), 79(11), 94(5), 122(7), 137(9), } \\
\mathbf{1 6 5 ( 1 0 0 )}\end{array}$ & - & \\
\hline & 18.3 & e & - & - & $\begin{array}{l}51(9), 65(12), 77(18), 91(25), 103(63), \\
131(41), 159(77), 175(32), 191(31) \\
\text { 205(50), 206(100) }\end{array}$ & - & \\
\hline & 25.9 & $f$ & - & - & $\begin{array}{l}\text { 77(7), 137(18), 202(8), 311(11), } 326 \\
(\mathbf{1 0 0 )}\end{array}$ & - & \\
\hline & 26.8 & g & - & - & $\begin{array}{l}\text { 77(24), 123(20), 137(22), 151(100), } \\
165(72), 192(62), 206(28), 370(27)\end{array}$ & - & \\
\hline & 27.1 & $\mathrm{~h}$ & - & - & $\begin{array}{l}79(11), 165(100), 203(16), 341(10), \\
384(20)\end{array}$ & - & \\
\hline & 27.3 & i & Cinnamic acid-related & & 145(49), 161(18), 192(100), 206(22) & {$[31]$} & Xanthorrhoea spp. \\
\hline & 28.4 & j & - & - & $\begin{array}{l}77(13), \mathbf{1 3 7}(100), 165(51), 208(41), \\
273(12), 384(8)\end{array}$ & - & \\
\hline \multirow[t]{6}{*}{ PRM27 } & 19.0 & - & Palmitic acid, methyl ester & Hexadecanoic acid, methyl ester & $\begin{array}{l}\text { 57(57), 74(100), 87(75), 99(16), } 143 \\
(21), 227(16), 270(12)\end{array}$ & NIST05 & Apis sp.; A. mellifera [32] \\
\hline & 20.7 & - & Oleic acid, methyl ester & 9-Octadecenoic acid, methyl ester & $\begin{array}{l}\text { 55(100), 69(70), 74(61), 83(57), } 97 \\
(52), 111(26), 123(20), 180(13), 222 \\
(20), 264(26), 296(5)\end{array}$ & NIST05 & \\
\hline & 20.9 & - & Stearic acid, methyl ester & Octadecanoic acid, methyl ester & $\begin{array}{l}\text { 55(28), 74(100), 87(73), 97(11), } 143 \\
(22), 199(8), 255(13), 298(14)\end{array}$ & NIST05 & \\
\hline & 25.8 & - & - & Tetracosanoic acid, methyl ester & $\begin{array}{l}\text { 74(100), 87(75), 99(29), 113(23), } 143 \\
(15), 339(8),[382(32)]\end{array}$ & NIST05 & \\
\hline & 27.0 & - & - & Nonacosane & $\begin{array}{l}\text { 57(100), 71(79), 85(61), 99(21), } 113 \\
(14), 127(10), 141(8),[408(2)]\end{array}$ & NIST05 & Apis sp. \\
\hline & 28.5 & - & - & Hentriacontane & $\begin{array}{l}\text { 57(100), 71(78), 85(59), 99(21), } 113 \\
(13), 141(7),[436(1)]\end{array}$ & NIST05 & \\
\hline
\end{tabular}


Table 2 Mass spectral data for significant components in each of the six museum artefacts (Continued)

\begin{tabular}{|c|c|c|c|c|c|c|c|}
\hline & 28.8 & - & Montanic acid, methyl ester & Octacosanoic acid, methyl ester & $\begin{array}{l}\text { 57(45), 74(100), 87(87), 143(33), } 395 \\
(17),[438(50)]\end{array}$ & NIST05 & Apis sp.; A. mellifera [32] \\
\hline & 30.9 & - & Melissic acid, methyl ester & Triacontanoic acid, methyl ester & $\begin{array}{l}57(51), 74(100), 87(91), 97(20), 129 \\
(12), 143(34), 423(17),[466(61)]\end{array}$ & NIST05 & \\
\hline & 31.9 & - & $\beta$-Amyrin & (3ß)Olean-12-en-3-ol & $\begin{array}{l}\text { 95(9), 119(10), 189(14), 203(44), } 218 \\
\text { (100), [426(5)] }\end{array}$ & NIST05 & $\begin{array}{l}\text { Canarium indicum; C. luzonicum; } \\
\text { C. salomonense }\end{array}$ \\
\hline & 32.1 & - & $\begin{array}{l}\text { 4,4,6a,6b,8a,11,11,14b-Octamethyl- } \\
\text { 1,4,4a,5,6,6a,6b,7,8,8a,9,10,11,12,12a,14, } \\
\text { 14a,14b-octadecahydro-2H-picen-3-one }\end{array}$ & Olean-12-en-3-one & $\begin{array}{l}\text { 55(15), 95(14), 203(79), 218(100), } \\
409(10),[424(20)]\end{array}$ & NIST05 & $\begin{array}{l}\text { Canarium indicum; } C \text {. } \\
\text { salomonense }\end{array}$ \\
\hline & 32.7 & - & a-Amyrin & (3ß)Urs-12-en-3-ol & $\begin{array}{l}\text { 69(32), 95(28), 135(27), 189(26), } 207 \\
(60), \mathbf{2 1 8 ( 1 0 0 )},[426(11)]\end{array}$ & NIST05 & $\begin{array}{l}\text { Canarium indicum; C. luzonicum; } \\
\text { C. salomonense }\end{array}$ \\
\hline \multirow[t]{4}{*}{ PRM28 } & 31.5 & - & $\begin{array}{l}\text { 4,4,6a,6b,8a,11,11,14b-Octamethyl- } \\
\text { 1,4,4a,5,6,6a,6b,7,8,8a,9,10,11,12,12a,14, } \\
\text { 14a,14b-octadecahydro-2H-picen-3-one }\end{array}$ & Olean-12-en-3-one & $\begin{array}{l}\text { 55(15), 95(24), 203(63), 218(100), } \\
\text { 409(7), [424(64)] }\end{array}$ & NIST05 & Canarium luzonicum \\
\hline & 31.9 & - & $\beta$-Amyrin & (3ß)Olean-12-en-3-ol & $\begin{array}{l}\text { 95(14), } 119(11), 189(13), 203(43), \\
\mathbf{2 1 8 ( 1 0 0 )},[426(5)]\end{array}$ & NIST05 & $\begin{array}{l}\text { Canarium indicum; C. Iuzonicum, } \\
\text { C. salomonense }\end{array}$ \\
\hline & 32.7 & - & a-Amyrin & (3ß)Urs-12-en-3-ol & $\begin{array}{l}\text { 69(38), 95(33), 135(14), 189(20), } 203 \\
(21), \mathbf{2 1 8 ( 1 0 0 )}, 411(23),[426(4)]\end{array}$ & NIST05 & \\
\hline & 34.4 & - & Lanostan-related & - & $\begin{array}{l}\text { 297(54), 393(26), 421(25), 453(100), } \\
{[468(23)]}\end{array}$ & NIST05 & Canarium luzonicum \\
\hline \multirow[t]{7}{*}{ PRM29 } & 30.5 & - & Ursadienol & Ursa-9(11), 12-dien-3-ol & $\begin{array}{l}\text { 55(14), 69(14) 119(10), 145(10), } 171 \\
(9), 189(5), 255(35), 406(13),[\mathbf{4 2 4} \\
(\mathbf{1 0 0 )}]\end{array}$ & NIST05 & Canarium salomonense \\
\hline & 31.1 & - & Ursadienone & Ursa-9(11),12-dien-3-one & $\begin{array}{l}\text { 55(61), 69(67), 133(24), 255(40), } 269 \\
(26), 407(13),[\mathbf{4 2 2 ( 1 0 0 ) ]}\end{array}$ & NIST05 & \\
\hline & 31.9 & - & $\beta$-Amyrin & (3ß)Olean-12-en-3-ol & $\begin{array}{l}\text { 95(16), } 119(11), 189(16), 203(48), \\
\mathbf{2 1 8 ( 1 0 0 ) ,}[426(6)]\end{array}$ & NIST05 & $\begin{array}{l}\text { Canarium indicum; C. luzonicum; } \\
\text { C. salomonense }\end{array}$ \\
\hline & 32.3 & - & a-Amyrin & (3ß)Urs-12-en-3-ol & $\begin{array}{l}\text { 69(14), 95(17), 135(18), 189(23), } 203 \\
(24), \mathbf{2 1 8 ( 1 0 0 )},[426(7)]\end{array}$ & NIST05 & Canarium salomonense \\
\hline & 32.7 & - & a-Amyrin & (3ß)Urs-12-en-3-ol & $\begin{array}{l}\text { 69(13), 95(15), 135(15), 189(20), } 203 \\
(21), \mathbf{2 1 8 ( 1 0 0 ) ,} 411(3),[426(9)]\end{array}$ & NIST05 & $\begin{array}{l}\text { Canarium indicum; C. luzonicum; } \\
\text { C. salomonense }\end{array}$ \\
\hline & 33.1 & - & a-Amyrin & (3ß)Urs-12-en-3-ol & $\begin{array}{l}\text { 69(14), 95(15), 135(15), 189(21), } 203 \\
(21), \mathbf{2 1 8 ( 1 0 0 ) ,} 411(3),[426(4)]\end{array}$ & NIST05 & Canarium salomonense \\
\hline & 33.7 & - & Ursene-related & - & $\begin{array}{l}\text { 57(33), 122(17), 135(16), 189(23), } \\
\text { 203(21), 218(100), 424(12), [454(6)] }\end{array}$ & NIST05 & \\
\hline
\end{tabular}

*Accepted taxonomic names as according to the International Plant Names Index (IPNI) at http://www.ipni.org.

Bold type denotes the species identification for the sample. 


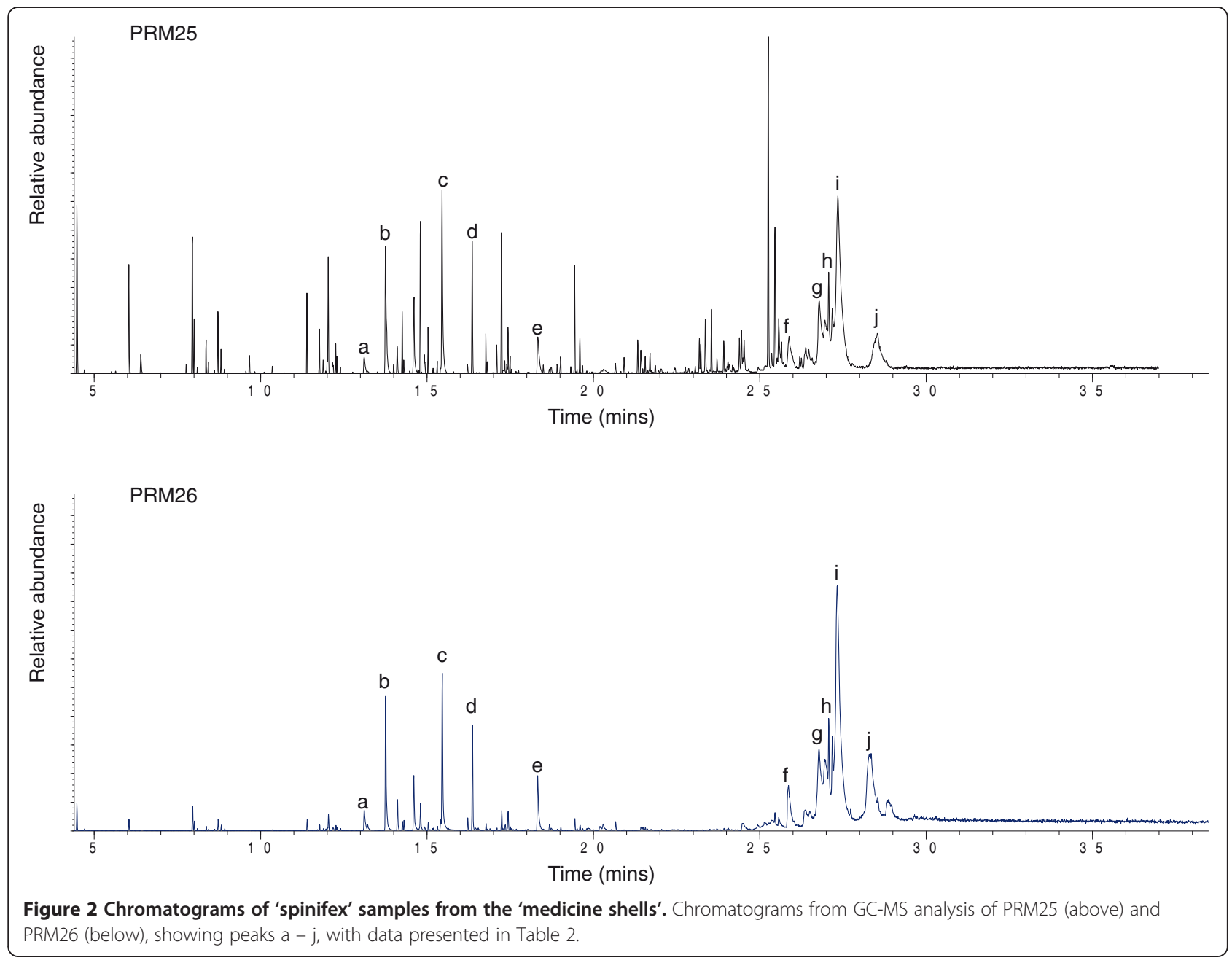

has more components (Table 2) in agreement with, and has therefore been tentatively identified as, Canarium luzonicum Miq., which is mentioned as a utilised species in the North Solomons province of Papua New Guinea [35]. The triterpenoid fraction of PRM27 is minor and cannot be identified to species at this stage. A direct comparison of PRM27 with Canarium bengalense has not yet been made, however the presence of this species is unlikely as it is native to the Philippines and not New Guinea. However, such identification would have implications for studies on trade.

A series of hydrocarbons, predominantly nonacosane and hentriacontane, plus the methyl esters of palmitic, oleic, stearic, tetracosanoic, montanic and melissic acids were also detected in PRM27, signifying a composite substance, and which may indicate a presence of beeswax $[22,32]$. No beeswax is evident in PRM28. This difference provides an explanation for the difference in character between the samples, whereby PRM27 is soft and waxy, and PRM28 is glassy and brittle (Table 1). It also concurs with the description of PRM27 originating from 'wild bees' nests'.

\section{Sample PRM29}

The PRM29 chromatogram shows a dominance of $\alpha$ amyrin, suggesting the resin is from the genus Canarium as was described on the label. The chromatogram was then compared with the modern reference sample of Canarium indicum, showing a similarity but not an exact match between the chromatograms. There was also little agreement between PRM29 and Canarium luzonicum. However, the presence of ursadienol and ursadienone, though in reduced amounts in the museum sample, is not present in C. indicum or C. luzonicum, but is a component of $C$. salomonense. All of the remaining peaks also correspond with the modern sample of $C$. salomonense (Table 2) and the PRM29 resin has therefore been identified as Canarium salomonense B.L.Burtt.

PRM29 was labelled as 'Canarium almond' and the results of the analysis indicated the identity of this resin as 
C. salomonense, which makes sense, as it is one of three species locally called Canarium almond, although a comparison with $C$. harveyi would be required to reinforce this identification. This species identification also makes sense geographically as the artefact is from Bougainville in the Northern Solomon province of Papua New Guinea, to which C. salomonense is native and commonly used.

There was no evidence of any tobacco mixed in with the resin, nor anything else such as burnt wood. This suggests that the resin is being stored in this packet ready to be mixed and smoked at a later time. The fact that the tobacco could be substituted for [24] suggests that the resin is as important as, if not more so than the tobacco for the narcotic or otherwise desired effect. The sacred aspect of $C$. salomonense in parts of the Solomon Islands [20] also needs to be considered with respect to the selection of resin used to produce the 'cool smoke', although this was not referred to by Blackwood [24] on collection of the artefact.

\section{Conclusions}

The first conclusion to be drawn from this study is that the original chemical composition of resins that have been curated in a museum for over a hundred years still remain intact enough to identify the botanical source of the resin to species. It is important that we make use of the collections, research and knowledge that has been stored and looked after for so long, particularly in the light of new analytical techniques. It is also worth noting that re-visiting and updating museum records for public access is equally important, particularly where there are discrepancies as have been noted in this study. In this small sample group, some ethnographic identifications are confirmed, and others are not. It is therefore important to note that species identification in museum records cannot be relied upon.

Six early-twentieth-century museum-curated resins from Australia and New Guinea have been chemically characterised by GC-MS, resulting in the identification of Xanthorrhoea resinosa Pers. as a raw material collected from the Blue Mountains in New South Wales, for use as an adhesive, and Canarium salomonense B.L. Burtt as a personal item stored carefully for later mixing with tobacco and smoking as a narcotic in Bougainville in Papua New Guinea. Two boxes of adhesive materials from Collingwood Bay in New Guinea have been characterised and one is thought to be a mixture of beeswax and Canarium spp., and the other possibly Canarium luzonicum Miq. Two samples of spinifex contained in 'medicine shells' from Western Australia hypothesised to be Triodia irritans R.Br. have been characterised molecularly and presented here (Figure 2, Table 2).
The integration of this new scientific data with existing ethnographic accounts of these and similar items contributes towards a wider understanding of the use of resins in Sahul. This study highlights the use of resin for less-well documented uses such as medicine and narcotics, as well as the more commonly referenced adhesives. The identification of resin from particular species used for specific purposes can offer insight into past use of natural materials and early adaptation to varying environments, plant exploitation practices and selection of resin-based materials, early knowledge of chemical properties of resins and the development of technologies, and cultural uses of resins for specific purposes. The methods used in this study show potential for similar identifications of resins from archaeological contexts and highlights the potential for developing a framework to allow the identification of archaeological resins more efficiently and effectively. This work demonstrates that resin analysis of museum artefacts is a useful tool for both ethnographic studies and archaeological research.

\section{Methods}

\section{Solvent extraction and derivitization}

A $1 \mathrm{mg}$ sample of material was removed from the resinous portion of each artefact. Each sample was dissolved in dichloromethane and methanol, derivitized via methylation using trimethyl(silyl)diazomethane in methanol and toluene (0.05:1:4) and transferred to vials in a dichloromethane solution.

\section{Gas chromatography-mass spectrometry analysis}

The samples were analysed by gas chromatography-mass spectrometry (GC-MS) using an Agilent 7820A GC system with a HP-5 ms 5\% Phenyl Methyl Silox capillary column, $30 \mathrm{~m} \times 250 \mu \mathrm{m} \times 0.25 \mu \mathrm{m}$, connected to an Agilent 5975 series MSD. Helium was the carrier gas at a constant flow rate of $1.2 \mathrm{~mL} / \mathrm{min} .1 \mu \mathrm{L}$ of sample was injected onto the column either splitless (PRM27, PRM28, PRM29) or at a 10:1 split ratio (PRM23, PRM25, PRM26), with the $\mathrm{GC}$ inlet maintained at $300^{\circ} \mathrm{C}$. The temperature of the oven was programmed at $50^{\circ} \mathrm{C}$, held for 2 minutes, then increased to $300^{\circ} \mathrm{C}$ at $10^{\circ} \mathrm{C} / \mathrm{min}$, where the temperature remained constant for 10 minutes. The column was directly inserted into the MS ion source, maintained at $230^{\circ} \mathrm{C}$, where electron impact (EI) spectra were obtained at $70 \mathrm{eV}$ with full scan from $\mathrm{m} / z 50$ to 800 .

\section{Data analysis}

The data collected are displayed as chromatograms showing the separation of the different components within the sample over time (heavier and more polar molecules take longer to elute out of the column), by relative abundance (how much of that compound is present in relation to the other components in the sample). Modern fresh resins 
acquired from the Royal Botanic Garden, Sydney, as well as ethnobotanical resins from the Economic Botany Collection at the Royal Botanic Gardens, Kew have formed the reference collection for this research. The same analytical methods were used for the reference resins as for the museum samples. Identifications were made through comparisons of the full series of components, with those from reference resins botanically identified to species, data from the literature and the NIST05 mass spectral library.

\section{Competing interests}

The author declares that they have no competing interests.

\section{Authors' contributions}

All work was carried out by the author. The author read and approved the final manuscript.

\section{Acknowledgements}

I would like to thank the Pitt Rivers Museum, Oxford for providing the samples for this study, and the Royal Botanic Gardens at Sydney and Kew for the reference collection. All analyses were undertaken at the Research Laboratory for Archaeology and the History of Art (RLAHA), University of Oxford, by the author. Many thanks go to Dr. Chris Green for assistance in creating Figure 1, as well as Dr. Michael Haslam and my supervisors Professor Mark Pollard and Dr. Alison Crowther for their comments. This work was supported by the Natural Environment Research Council [grant number NE/ $1528518 / 1$, as part of a DPhil project.

Received: 24 July 2013 Accepted: 28 November 2013

Published: 5 December 2013

\section{References}

1. Attenbrow $V$, Robertson $G$, Hiscock P: The changing abundance of backed artefacts in south-eastern Australia: a response to Holocene climate change? J Archaeol Sci 2009, 36(12):2765-2770

2. Hiscock $P$, Veth $P$ : Change in the Australian desert culture: a reanalysis of tulas from Puntutjarpa rockshelter. World Archaeol 1991, 22(3):332-345.

3. Lampert R, Steele D: Archaeological studies at Bomaderry Creek, New South Wales. Rec Aust Mus 1993, 17:55-75.

4. Robertson G: Aboriginal craft and subsistence activities at Native Well I and Native Well II, Central Western Highlands, Queensland: results of a residue and use-wear analysis of backed artefacts. Terra Australis 2009, 30:239-257.

5. Dickson FP: Australian stone hatchets: a study in design and dynamics. Sydney: Academic Press; 1981.

6. Wadley L: Putting ochre to the test: replication studies of adhesives that may have been used for hafting tools in the Middle Stone Age. J Hum Evol 2005, 49(5):587-601.

7. Blee AJ, Walshe K, Pring A, Quinton JS, Lenehan CE: Towards the identification of plant and animal binders on Australian stone knives. Talanta 2010, 82(2):745-750.

8. Thorley P: A resin-hafted stone implement from the middle palmer river Catchment. Central Australia. Aust Archaeol 1999, 3(48):45.

9. Pitman $H$, Wallis $L$ : The point of Spinifex: Aboriginal uses of spinifex grasses in Australia. Ethnobot Res App/ 2012, 10:109-131.

10. Pitt rivers museum object catalogue. http://objects.prm.ox.ac.uk

11. Australian museum collection. http://australianmuseum.net.au.

12. Gould R, Koster D, Sontz A: The Lithic assemblage of the western desert aborigines of Australia. Am Antiq 1971, 36(2):149-169.

13. Summerhayes GR, Leavesley M, Fairbairn A, Mandui H, Field J, Ford A, Fullagar R: Human adaptation and plant use in highland New Guinea 49,000 to 44,000 years ago. Science $2010,330(6000): 78-81$

14. Rots $\mathrm{V}$, Williamson BS: Microwear and residue analyses in perspective: the contribution of ethnoarchaeological evidence. J Archaeo/ Sci 2004, 31(9):1287-1299.

15. Langenheim JH: Plant Resins: chemistry, evolution, ecology, and ethnobotany. Cambridge: Timber Press; 2003

16. Cribb AB, Cribb JW: Useful wild plants in Australia. Sydney: Collins; 1981
17. Gamage HK, Mondal S, Wallis LA, Memmott P, Martin D, Wright BR, Schmidt S: Indigenous and modern biomaterials derived from Triodia (spinifex) grasslands in Australia. Aust J Bot 2012, 60:114-127.

18. Parr J: Once, twice maybe, but not three times: Reheating Xanthorrhoea australis resin. Aust Archaeol 1999, 49:23-27.

19. Binford LR: An alyawara day: flour, spinifex gum, and shifting perspectives. J Anthropol Res 1984, 40(1):157-182. Fortieth Anniversary Issue 1944-1984.

20. McClatchey W, Sirikolo MQB, Kaleveke L, Pitanapi C: Differential conservation of two species of Canarium (Burseraceae) among the Babatana and Ririo of Lauru (Choiseul), Solomon Islands. Econ Bot 2006, 60(3):212-226

21. Clement E, Schmeltz J: Ethnographical notes on the Western-Australian Aborigines: with a descriptive catalogue of a collection of Ethnographical objects from Western Australia. Int Arch Ethnogr 1904, 16:1-29.

22. de la Cruz-Cañizares J, Doménech-Carbó M, Gimeno-Adelantado J, MateoCastro R, Bosch-Reig F: Study of Burseraceae Resins used in binding media and varnishes from artworks byGgas Chromatography-Mass Spectrometry and Pyrolysis-Gas chromatography-mass spectrometry. J Chromatogr A 2005, 1093:177-194.

23. Ribechini E, Orsini S, Silvano F, Colombini MP: Py-GC/MS, GC/MS and FTIR Investigations on late roman-egyptian adhesives from opus sectile: new insights into ancient recipes and technologies. Anal Chim Acta 2009 638(1):79-87.

24. Blackwood B: Both sides of Buka passage. Oxford: Oxford University Press; 1935

25. Blackwood B: The Kukukuku of the Upper Watut. Oxford: Oxprint: 1978.

26. Merrill ED: Tobacco in New Guinea. Am Anthropol 1930, 32:101-105.

27. Baumer $U$, Dietemann P: Identification and differentiation of dragon's blood in works of art using gas chromatography/mass spectrometry. Anal Bioanal Chem 2010, 397(3):1363-1376.

28. Burger $P$, Charrié-Duhaut A, Connan J, Flecker M, Albrecht P: Archaeological Resinous Samples from Asian Wrecks: taxonomic characterization by GC-MS. Anal Chim Acta 2009, 648(1):85-97.

29. Stacey RJ, Cartwright CR, Mcewan C: Chemical characterization of ancient mesoamerican 'Copal' Resins: Preliminary Results. Archaeometry 2006, 48(2):323-340

30. Steigenberger G, Herm C: Natural resins and balsams from an eighteenthcentury pharmaceutical collection analysed by gas chromatography/ mass spectrometry. Anal Bioanal Chem 2011, 401(6):1771-1784.

31. Modugno F, Ribechini E, Colombini MP: Aromatic Resin Characterisation by Gas chromatography-mass spectrometry: raw and archaeological materials. J Chromatogr A 2006, 1134:298-304.

32. Bonaduce I, Colombini MP: Characterisation of beeswax in works of art by gas chromatography-mass spectrometry and pyrolysis-gas chromatographymass spectrometry procedures. J Chromatogr A 2004, 1028:297-306.

33. de Silva DSM, Memmott P. Flutter N, Martin D: Characterization of Spinifex ( Triodia pungens) Resin and Fibres, Conference Abstracts: 11th Pacific Polymer Conference, PPC11: Progress Polymers for the New Millenium. 11th Pacific Polymer Conference 2009 incorporating the 31st Australian Polymer Symposium. 2009:2-3.

34. Maiden JH: The useful native plants of Australia:(including Tasmania). Sydney: Turner and Henderson; 1889.

35. Holdsworth D: Traditional medicinal plants of the North Solomons province, Papua New Guinea. Q J Crude Drug Res 1908, 18:33-44.

doi:10.1186/2050-7445-1-36

Cite this article as: Bradshaw: Chemical characterisation of museumcurated ethnographic resins from Australia and New Guinea used as adhesives, medicines and narcotics. Heritage Science 2013 1:36. 